\title{
AUTORREGULAÇÃO DA APRENDIZAGEM DE LÍNGUA ESTRANGEIRA NO CURSO TÉCNICO EM EVENTOS: UMA EXPERIÊNCIA FORMADORA
}

\author{
Adriana Guimarães de Oliveira ${ }^{1}$ \\ Dirceu Pereira dos Santos ${ }^{2}$ \\ José Augusto Ferreira da Silva ${ }^{3}$
}

\begin{abstract}
Resumo
$\mathrm{O}$ artigo relata o planejamento e aplicação de uma sequência didática criada com alunos do Curso Técnico em Eventos do Instituto Federal Fluminense Campus Cabo Frio, na disciplina de Língua Inglesa. Com o objetivo de mobilizar os alunos para a pesquisa e apresentação de palavras associadas a eventos, a sequência didática consistiu na promoção da autorregulação da aprendizagem, embasada na afetividade. As atividades evocaram memórias relacionadas aos eventos sociais vivenciados, construindo o vocabulário a ser estudado. O perfil da turma foi traçado por meio de questionário que evidenciou a experiência escolar com a |Língua Inglesa. Com o vocabulário estruturado a partir das experiências afetivas, o ensino se deu de forma colaborativa. Para os alunos, tratou-se de uma rica experiência.
\end{abstract}

Palavras-chave: Sequência Didática; Autorregulação da Aprendizagem; Afetividade; Língua Inglesa; Autonomia.

\section{SELF-REGULATION OF FOREIGN LANGUAGE LEARNING IN THE TECHNICAL COURSE IN EVENTS: AN ENHANCING EXPERIENCE}

\begin{abstract}
This paper aims to report the planning and implementation of a didactic sequence for the English language learning. It has been developed with students attending the Technical Course in Events at the Fluminense Federal Institute Campus Cabo Frio. With the purpose of mobilizing such students for research and subsequent classroom presentation of words associated with events, the didactic sequence sought to promote self-regulated learning, grounded in affectivity. The designed activities evoked memories related to the social events experienced, thus building up the vocabulary to be studied. Students' English learning backgrounds were accessed by means of a questionnaire, which made it possible to outline the class profile. Keeping all vocabulary structured from affective experiences favoured collaborative teaching, leading students to a valuable experience.
\end{abstract}

Keywords: Self-regulation; Didactic Sequence; English Language; Autonomy.

\footnotetext{
${ }^{1}$ Instituto Federal de Educação, Ciência e Tecnologia Fluminense. E-mail: adriana.oliveira@iff.edu.br

${ }^{2}$ Instituto Federal de Educação, Ciência e Tecnologia Fluminense. E-mail: dirceu.santos@iff.edu.br

${ }^{3}$ Instituto Federal de Educação, Ciência e Tecnologia Fluminense. E-mail: jasilva@iff.edu.br
} 


\section{INTRODUÇÃO}

Fruto dos estudos e pesquisas desenvolvidos no mestrado profissional do Instituto Federal Fluminense (IFFluminense), pelo Programa de Pós-Graduação em Educação Profissional e Tecnológica, apresenta-se, aqui, o relato do produto educacional construído e aplicado em uma turma real, a partir da vivência do ensino de Língua Inglesa, em turmas de curso técnico concomitante e subsequente ao ensino médio.

O produto educacional produzido foi uma sequência didática, com foco na promoção da autorregulação da aprendizagem e na afetividade, aplicada na turma do terceiro módulo do Curso Técnico em Eventos no IFFluminense Campus Cabo Frio, no ano de 2019. Por sequência didática, entende-se "um modo de o professor organizar as atividades de ensino em função de núcleos temáticos e procedimentais" (ARAÚJO, 2013, p. 323). O conceito se tornou conhecido no Brasil, a partir das pesquisas de Dolz, Noverraz e Schneuwly, sobre a relação entre linguagem, interação e sociedade. Para esse grupo de autores, a sequência didática é um conjunto de atividades organizadas de forma sistemática, em torno de um gênero textual oral ou escrito (ARAÚJO, 2013). É ainda considerada "um conjunto de atividades progressivas, planificadas, guiadas ou por um tema, ou por um objetivo geral, ou por uma produção dentro de um projeto de classe" (CRISTOVÃO, 2009 apud CORREA, BRITO E TOGNATO, 2018, p. 30).

Partindo do conceito da sequência didática, saindo da esfera específica do gênero textual oral e escrito, o que fica é a apreciação de que essa metodologia de ensino pode ser considerada um instrumento de mediação entre os alunos e os saberes a serem desenvolvidos, uma vez que as atividades são guiadas por um tema, o que promove a autonomia em classe.

Nessa perspectiva, para o ensino da Língua Inglesa, considerando os alunos que frequentam os cursos técnicos subsequentes ou concomitantes, o desenvolvimento da autorregulação da aprendizagem e a abordagem afetiva surgem como possibilidades de construção da autonomia, favorecendo e facilitando a aprendizagem. Sendo assim, a produção de uma sequência didática que viabilize uma proposta de ensino autorregulada e afetiva, buscando conferir ao aluno do Curso Técnico em Eventos a chance de gerir pensamentos, sentimentos e atitudes mais autônomas, flexíveis e responsáveis, é o objetivo primeiro do produto educacional proposto. 
O resultado das atividades desenvolvidas e apresentadas pelos alunos revelou-se uma experiência formadora para a professora, suscitando, portanto, a necessidade de maiores reflexões sobre a formação continuada para os docentes.

Propõe-se nesse artigo apresentar o processo metodológico e a aplicação da sequência didática, bem como analisar os resultados e as situações experienciadas com os alunos, ampliando o olhar sobre o processo de ensino da Língua Inglesa nos cursos de educação profissional.

\section{A AUTORREGULAÇÃO DA APRENDIZAGEM}

Com relação à aprendizagem, a autorregulação é compreendida como "um processo em que o aluno estrutura, monitora e avalia o seu próprio aprendizado" (ZIMMERMAN \& SCHUNK apud GANDA E BORUCHOVITCH, 2018, p. 71).

As ações de estruturar, monitorar e avaliar a aprendizagem não acontecem aleatoriamente e nem são habilidades inatas. Então, na relação com a aprendizagem, a autorregulação é uma habilidade que o indivíduo adquire ao longo da vida, a partir de suas próprias experiências, do ensinamento de outras pessoas e da interferência do ambiente em que se insere (GANDA E BORUCHOVITCH, 2018). É possível concluir que a capacidade de se autorregular, sem a intervenção externa, é construída pelo indivíduo, na relação com o outro, a partir das intervenções e mediações que ocorrem na dinâmica social.

Polydoro e Azzi (2009) dizem que o tema da autorregulação vem sendo investigado por diversas abordagens da psicologia, e por diferentes autores. Dentre as teorias da psicologia, a mais difundida é a Teoria Social Cognitiva, que vem orientando o trabalho e pesquisa de professores e psicólogos. Essa teoria parte do pressuposto de que há uma reciprocidade entre os fatores pessoais, comportamentais e ambientais no funcionamento humano (GANDA E BORUCHOVITCH, 2018).

O papel da autorregulação no exercício da agência humana, quer dizer, na capacidade do homem intervir intencionalmente em seu ambiente, tem sido destacado por Polydoro e Azzi (2009). Para as autoras, as pessoas "não apenas reagem ao ambiente externo, mas possuem a capacidade de refletir sobre ele, antecipar cognitivamente cenários construídos por ações e seus efeitos, de forma a vislumbrar e escolher cursos de ação que julgarem mais convenientes ou necessários" (ibid, p. 75). 
O desenvolvimento de pesquisas sobre a autorregulação vem se intensificando, desde os meados da década de 1980, principalmente no contexto educacional, em que se busca descobrir a forma pela qual os alunos podem se tornar autônomos no seu processo de aprendizagem, sendo capaz de regulá-lo. Com base em diferentes autores, Ganda e Boruchovitch (2018) dizem que "a literatura revela que os alunos mais autorregulados têm melhor aproveitamento da aprendizagem no ambiente escolar e apresentam maior desempenho e motivação diante dos estudos". Os teóricos apontam, ainda, que a dimensão social que abarca toda a comunidade escolar (pais, professores, colegas) e o contexto econômico/cultural, de fato, podem influenciar o aprendizado do aluno. Afirmam, ainda, que

além das crenças pessoais, da motivação e do uso de estratégias de aprendizagem, outro importante fator que perpassa todas as etapas do processo de autorregulação é a emoção/sentimento. Os estados emocionais, formados por componentes fisiológicos, cognitivos e comportamentais, se manifestam antes, durante e após a realização de uma atividade. As emoções podem afetar a aprendizagem em um sentido positivo ou negativo, dependendo de sua intensidade, das características particulares do aluno, das estratégias cognitivas e metacognitivas, conhecidas e usadas por ele, do apoio social que recebe e até mesmo do contexto cultural no qual está inserido (GANDA E BORUCHOVITCH, 2018, p. 74).

Destarte, o controle emocional tem um papel fundamental na autorregulação. Daí a necessidade, mais que emergente, das emoções adentrarem as salas de aula, em todos os níveis de ensino. No entanto, a história da educação brasileira abre pouco espaço à promoção das habilidades socioemocionais, fato percebido no próprio Plano Nacional de Educação (PNE), lançado em 2014, estruturador de um Sistema Nacional de Educação, que apresenta metas voltadas somente para as atribuições cognitivas, assim como no monitoramento da educação por meio do Índice de Desenvolvimento da Educação Básica (IDEB), que mede índices de aprovação em exames padronizados, sem a consideração dessas habilidades.

As habilidades socioemocionais podem ser compreendidas como parte fundamental da formação humana. Lidar com as próprias emoções, autoconhecer-se e relacionar-se com os outros envolve cooperação e a capacidade de resolver problemas na gerência dos objetivos da vida. Essas habilidades socioemocionais, portanto, interferem sobremaneira na formação humana e profissional do ser, e "não é mais possível conceber que apenas a cognição compareça à sala de aula" (ABED, 2014, p. 8).

Sobre afetividade e a aquisição de uma segunda língua, salienta-se que o ensino afetivo "representa a esperança de aperfeiçoar as atitudes, a motivação, a autoconfiança e os níveis de 
ansiedade" (CITTOLIN, 2003, p.1), fatores que descomplexificam o ensino e a aprendizagem, faces de uma mesma moeda.

Razão e afeto são temas envoltos em dicotomias e dilemas. "Desde os filósofos gregos da Antiguidade, razão e afeto foram apartados, sendo a razão considerada nossa característica humana superior, aquela que efetivamente nos caracteriza como humanidade" (SOLIGO, 2018, p. 9). Continuando, Soligo diz que, nesse contexto, as emoções e os afetos seriam nossa porção primitiva e, para garantia de nossa condição humana, deveria ser controlada e eliminada.

$\mathrm{Na}$ Idade Média, na filosofia teológica, a racionalidade era o que nos aproximava de Deus, e portanto, nos conferia humanidade. Assim,

afetos deveriam ser evitados, expurgados. A partir de uma perspectiva de mundo masculina, calcada nas relações que conferiam aos homens o lugar de poder, o pensamento dominante da época atribuía às mulheres o domínio dos afetos, justificando assim sua posição sempre subalterna aos homens, dotados da valorizada racionalidade (SOLIGO, 2018, p. 10).

Conforme elucida Soligo (2018), no século XVII, a ideia da razão como condição de existência foi reiterada pelo filósofo René Descartes (1596-1650) com o axioma “Cogito, ergo sum” (Penso, logo existo). No século XVIII, do mesmo modo, os iluministas franceses defendiam a importância do pensamento racional, em oposição às crenças religiosas e os atos movidos pelos afetos.

Ainda tratando da história, Soligo (ibid) diz que, no século XIX, ao afirmar a prevalência do pensamento científico sobre as demais formas de compreensão do mundo, o positivismo preconiza a objetividade e a neutralidade como condições da ciência, apagando a subjetividade e o afeto dos campos da ciência, da produção e da educação.

Também no campo da Sociologia, a razão se apresenta como critério para definição e adaptação à ordem social, em oposição à primitividade dos afetos. Essa ideia é alimentada por Durkhein (1858-1917), ao falar de uma educação que fosse capaz de transformar a criança de um ser naturalmente selvagem para um indivíduo socializado, apto à vida em sociedade, adequada à ordem capitalista que se desenvolvia na Europa (SOLIGO, 2018).

Na perspectiva de Marx (1818-1883), a racionalidade ainda prevalece, mas, diferente de Durkhein, não vinculada aos critérios de adaptabilidade social, "mas como condição de superação da alienação imposta pelo sistema capitalista" (ibid, p. 11).

Com o desenvolvimento da Psicologia, que se apresenta como ciência a partir do século XIX, o mesmo movimento é observado: a razão ainda é vista "como condição humana 
primordial e indicadora de amadurecimento psicológico" (ibid, p.11), mesmo que tenha dedicado parte significativa de seus estudos à compreensão das emoções e dos afetos.

Esse breve resumo

...ajuda a compreender as razões do predomínio da concepção dualista no pensamento ocidental e do domínio da razão sobre a emoção. Da mesma forma, possibilita entender a ausência da dimensão afetiva no pensamento pedagógico e educacional dos sistemas de ensino nos diversos países. Concretamente, isto significa que as políticas educacionais e o próprio pensamento pedagógico desenvolveram-se a partir do pressuposto de que a dimensão afetiva não participa do processo de ensino e aprendizagem, o qual pode ser explicado e planejado apenas em função dos aspectos cognitivos. E mais, que é possível desenvolver a dimensão cognitiva sem interferir ou sem que seja influenciada pela dimensão afetiva. (LEITE, 2018, p. 29).

A concepção dualista razão/emoção vê o sujeito como alguém que ora pensa, ora sente, sem vínculo entre estas dimensões. Em oposição, visando à superação da concepção dualista, está a concepção monista, que vai reinterpretar a relação entre razão e emoção.

É somente na segunda metade do século XX, pela influência da concepção monista, que surgem estudos pioneiros sobre a dimensão afetiva nas relações de ensino-aprendizagem, em sala de aula, a partir dos estudos de Piaget (1896-1980), Vygotsky (1896-1934) e Wallon (18791962), no advento das teorias interacionistas, conforme aponta Leite (2018).

Por afetividade, entende-se um "conjunto de fenômenos psíquicos que se manifestam sob a forma de emoções, sentimentos e paixões, acompanhados sempre de impressão de dor ou prazer, de satisfação ou insatisfação, de agrado ou desagrado, de alegria ou de tristeza" (CODO \& GAZZOTTI, 1999 apud BEZERRA, 2006, p. 21).

A compreensão do conceito de afetividade é importante para o estabelecimento da relação entre a construção do vocabulário da Língua Inglesa e as atividades autorreguladas, a serem propostas aos alunos do Curso Técnico em Eventos.

Para Vygostsky, "o processo de desenvolvimento humano ocorre a partir das situações de aprendizagem, envolvendo as experiências vivenciadas nos diversos contextos sociais que a cultura possibilita, onde o papel do outro é fundamental” (LEITE, 2018, p. 32). Rego (2011) diz que, ao longo dos escritos de Vygotsky, é possível perceber, mesmo de modo implícito, sua profunda preocupação em integrar os aspectos cognitivos e afetivos do funcionamento psicológico humano. A autora afirma que "Vygotsky concebe o homem como um ser que pensa, raciocina, deduz e abstrai, mas também como alguém que sente, se emociona, deseja, imagina e se sensibiliza" (REGO, 2011, p. 120), conforme as palavras do próprio autor: 
....a fertilidade de nosso método pode ser demonstrado também em outras questões concernentes às relações entre as funções, ou entre a consciência como um todo e suas partes. Uma breve referência a pelo menos uma dessas questões indicará a direção que nossos estudos futuros poderão tomar, e demonstrará a importância do presente estudo. Referimo-nos à relação entre intelecto e afeto. A sua separação enquanto objetos de estudo é uma das principais deficiências da psicologia tradicional, uma vez que esta apresenta o processo de pensamento como um fluxo autônomo de "pensamentos que pensam a si próprios", dissociado da plenitude da vida, das necessidades e dos interesses pessoais, das inclinações e dos impulsos daquele que pensa. (VYGOTSKY, 2008, p.9)

Como é possível observar, na perspectiva de Vygotsky, "cognição e afeto não se encontram dissociadas do ser humano, pelo contrário, se inter-relacionam e exercem influências recíprocas ao longo de toda a história do desenvolvimento do indivíduo" (REGO, 2011.p. 122), o que torna impossível compreendê-los separadamente.

Vygotsky "prevê que o Homem é o único animal superior com inúmeras possibilidades de desenvolvimento das funções superiores mais complexas, desde que esteja inserido em um ambiente sociocultural adequadamente organizado" (LEITE, 2018, p. 33). Assim, sua concepção sobre o aprendizado decorre da compreensão do homem como um ser que se forma em contato com a sociedade. Com relação à educação, o conceito de mediação surge como uma das grandes contribuições, pois considera que todo aprendizado é necessariamente mediado, o que torna o papel do ensino e do professor mais ativo e determinante.

Conclui-se, portanto, que, se para Vygotsky cognição e afeto não se dissociam do indivíduo, a afetividade nas salas de aula ganha papel relevante. Segundo ele, a escola, "por oferecer conteúdos e desenvolver modalidades de pensamento bastante específicos, tem um papel diferente e insubstituível, na apropriação pelo sujeito da experiência culturalmente acumulada" (REGO, 2011, p. 103).

Apropriando-se das ideias de Vygotsky, advoga-se que o desenvolvimento da afetividade na sala de aula pode servir de mediação entre os conhecimentos a serem trabalhados em Língua Inglesa no Curso Técnico em Eventos com os eventos que marcaram a história de cada um dos alunos, porque permeados de sensações e afetos. Tal concepção alicerça o produto educacional produzido. 


\section{A AUTORREGULAÇÃO DA APRENDIZAGEM E A EDUCAÇÃO PROFISSIONAL}

A trajetória da Educação Profissional no Brasil está envolta em tessituras que expressam o contexto histórico de cada período, com toda sua implicação política e econômica.

"O primeiro encontro entre Educação e Trabalho no Brasil remonta às atividades de desenvolvimento da economia de subsistência e particularmente de incremento à extração de minérios em Minas Gerais"(BEZERRA, 2013, p.16), ainda no período colonial. As escolas-oficinas constituíram os primeiros núcleos de formação profissional de artesãos e demais ofícios, e tinham sede nos colégios e nas residências dos jesuítas (BEZERRA, 2013).

Os religiosos que vieram para o Brasil, trazidos pela Companhia de Jesus, colaboraram na preparação da mão-de-obra especializada, desde o período colonial, dando início à dualidade entre a educação oferecida à elite e a educação oferecida aos desvalidos da sorte.

A educação oferecida pelos jesuítas criou uma mentalidade que levou ao desprezo pelo ensino de ofícios, devido ao seu caráter assistencialista; e quando o ensino profissional foi incorporado ao conjunto geral de instrução, continuou a ser considerado deprimente e desmoralizante (CAMPELLO E FILHO, 2019).

No século XX, a partir dos anos 30, o processo de industrialização modificou, paulatinamente, a sociedade brasileira, tornando necessária uma mudança na proposta de educação. Era preciso preparar os trabalhadores para a indústria, e a preparação de mão-de-obra especializada implicou uma mudança de concepção do ensino profissional. Era preciso desvincular o ensino profissional da aprendizagem de um ofício e caminhar para uma aprendizagem que introduzisse o domínio das técnicas e de adaptação às máquinas, disciplinando a força de trabalho, adequando-a à organização fabril (CAMPELLO E FILHO, 2019). O ensino profissional deixou de ter caráter assistencialista e entrou em cena a educação profissional, em atendimento à nova demanda da sociedade. Nesse contexto, a educação profissional firmou-se numa relação conturbada entre trabalho e educação, estando ainda voltada para os menos favorecidos. As Reformas Educacionais e as Leis de Diretrizes e Bases desse período não alteraram a realidade e, ao longo do século XX, o Ensino Médio, etapa voltada à educação profissional, esteve direcionado para o atendimento ao mercado de trabalho, formando mão-de-obra qualificada, alimentando a dualidade estrutural entre os que planejam (minoria composta pela elite) e os que executam (maioria composta pela classe trabalhadora) (KUENZER, 2009).

Ao final do século XX, a nova (e atual) Lei de Diretrizes e Bases da Educação Nacional (LDB), Lei 9394/96, reconfigurou a identidade do ensino médio, considerando-o uma etapa de 
consolidação da educação básica, possibilitando o prosseguimento de estudos. E, pela primeira vez, a partir de 2008, a educação profissional passou a fazer parte da lei que rege a educação brasileira, ganhando um capítulo específico. E, de educação profissional para o atendimento ao mercado de trabalho, procurou sustentar-se na concepção de educação para o trabalho.

Com muitas discussões e políticas educacionais, os conceitos introduzidos na educação profissional e tecnológica no século XXI buscam a consolidação para a formação profissional do trabalhador que, em atendimento à LDB, pode naturalmente prosseguir nos estudos. Nessa conjuntura, no ano de 2008, pela Lei 11.892, nascem os Institutos Federais de Educação, Ciência e Tecnologia, atuando como instituições de educação superior, básica e profissional, especializados na oferta de educação profissional e tecnológica nas diferentes modalidades de ensino, e, que desde então, vêm exercendo forte influência para a consolidação da educação profissional voltada para a formação cidadã da classe trabalhadora. E é nessa instituição, com essa perspectiva de educação profissional, que está o Curso Técnico em Eventos.

Com a história da educação profissional no Brasil essencialmente associada à dualidade de oferta na educação nacional, é perceptível a dificuldade existente entre tantos de perceber o ensino para além da racionalidade técnica. Então, propor o trabalho de autorregulação da aprendizagem escolar em um curso técnico, tendo a afetividade como elemento alargador das potencialidades para sua construção, não é tarefa simples, principalmente em um componente curricular que, por excelência, tem uma história construída sob a base de dificuldade de compreensão, de exclusão e segregação profissional entre os que dominam e os que não dominam os conhecimentos da área, como é o caso da língua estrangeira, aqui representado pela Língua Inglesa.

O processo de autorregulação da aprendizagem, exercido em uma turma do Curso Técnico em Eventos, no Instituto Federal Fluminense Campus Cabo Frio, no trabalho com a Língua Inglesa, mostrou-se um caminho possível para a emancipação do trabalhador, na assunção do seu lugar de sujeito e de cidadão que se deseja formar.

A sequência didática foi desenvolvida em um dos semestres do curso, no período em que a Língua Inglesa tem o caráter instrumental, voltada para um fim específico, cujo objetivo é a aquisição de vocabulário destinado à área de eventos. $\mathrm{O}$ trabalho mobilizou a professora e os alunos em tarefas conjuntas, colocando a afetividade como elemento mediador para a construção do vocabulário estudado, em uma turma que trazia grandes lacunas no conhecimento da língua inglesa trabalhada ao longo do processo de escolarização. 


\section{PERCURSO METODOLÓGICO}

Com a proposta metodológica pautada na abordagem qualitativa, a pesquisa realizada caracterizou-se como pesquisa-ação, porque pode ser utilizada para aprimorar o ensino e, consequentemente, o aprendizado dos alunos (TRIPP, 2005). A pesquisadora é a professora de Língua Inglesa da referida turma.

Para a elaboração do conjunto de tarefas que compõem a sequência didática, o Projeto Pedagógico do Curso foi revisitado e analisado, de maneira que o recorte sobre o módulo do curso fosse feito em totalidade, sem a fragmentação da proposta do ensino da língua.

O Curso Técnico em Eventos, que compõe o eixo tecnológico Turismo, Hospitalidade e Lazer, é ofertado na forma concomitante, no turno noturno, organizado em módulos, com três semestres letivos. Em um deles, a Língua Inglesa é trabalhada de forma geral, buscando levantamento dos conhecimentos prévios dos alunos com relação ao idioma, tomando como base a proposta curricular pertinente ao Ensino Médio, e em outro, tem uma abordagem instrumental.

A abordagem instrumental foi introduzida no Brasil na década de 1970, com a perspectiva de atender à demanda nacional da época. Ao longo do tempo, pesquisadores e professores abandonaram-na, talvez por incompreensões teóricas que geraram mitos a seu respeito (BEATO-CANATO, 2011). De acordo com Ferreira e Rosa (2008), o objetivo principal do Inglês Instrumental, ou Inglês para Fins Específicos (ESP), é capacitar o aluno a ler e compreender textos acadêmicos em inglês, usando estratégias e técnicas de leitura específicas, num esquema de atividades de caráter autônomo.

Dizem as referidas autoras que, mesmo que o aluno seja o protagonista nessa concepção social de leitura, o professor desempenha um papel de destaque nesse processo de construção conjunta, pois a ele caberá o processo de acompanhamento e auxílio ao aluno até que venha a assumir a responsabilidade pelo seu desenvolvimento, demonstrando estar apto a realizar as atividades com independência e autonomia (FERREIRA e ROSA, 2008). O ensino da gramática se dá de forma contextualizada e o vocabulário trabalhado relaciona-se, principalmente, com a área de estudo do aluno. Para um curso técnico concomitante, com a duração de um ano e meio, o Inglês para fins Específicos se mostra apropriado. As estratégias e metodologia de trabalho a serem desenvolvidas é que darão o tom da sua especificidade. 
Baseada no referencial teórico, levando em conta a relevância da autorregulação da aprendizagem e da afetividade, tal sequência foi desenhada e aplicada na turma, no primeiro semestre do ano letivo de 2019. A sequência didática foi trabalhada em dez encontros com a turma, com 2 h/a por encontro, computando carga horária total de 20h/a. Seu objetivo geral foi mobilizar os alunos para a pesquisa, produção e apresentação de eventos, apropriando-se de vocabulário específico em Língua Inglesa, por intermédio do desenvolvimento da autonomia e da autoconfiança. As atividades propostas, geradas no princípio da autorregulaçao da aprendizagem, seguiram o caráter de coletividade e socialização dos conhecimentos, produzidos a partir das histórias e memórias de cada um, permeadas de afetividade.

A turma, composta por vinte e três alunos, com uma frequência regular de vinte e dois alunos por aula, tem, em sua maioria, trabalhadores que trazem na bagagem as histórias e experiências vividas em diferentes contextos escolares, em diferentes momentos da vida, fato perceptível pela diferença de idade apresentada.

Tabela 1. Estabelecimento do perfil da turma do curso de Técnico em Eventos.

\begin{tabular}{l|c} 
Idades & $\begin{array}{c}\text { Total de } \\
\text { alunos }\end{array}$ \\
\hline $\mathbf{1 6}$ a 20 & 13 \\
\hline 21 a 25 & 5 \\
\hline 26 a 30 & - \\
\hline 31 a 35 & - \\
\hline 36 a 40 & 1 \\
\hline 41 a 45 & 1 \\
\hline 46 a 50 & 1 \\
\hline 51 a 56 & 1 \\
\multicolumn{2}{|c}{ Fonte: Dos autores, 2019.}
\end{tabular}

Para levantamento de questões pertinentes ao relacionamento dos alunos com a Língua Inglesa, bem como sobre questões pontuais acerca dos vínculos afetivos necessários à significação da aprendizagem e o conhecimento dos aspectos socioemocionais da turma, aplicou-se um questionário, no início do módulo em questão. Com os dados do questionário supracitado, delineou-se o perfil da turma. As questões foram tabuladas e analisadas e colaboraram para a reflexão dos temas e formulação das ideias abordadas.

Do total de alunos, treze pessoas são do gênero feminino, oito masculino, e um não se identificou. Dezoito anos é a menor idade apresentada, enquanto cinquenta e seis é a maior, o que reflete a heterogeneidade da turma. Apenas um aluno não teve o ensino da Língua Inglesa no período escolar. 
Figura 1. Contato da Língua Inglesa na trajetória escolar.

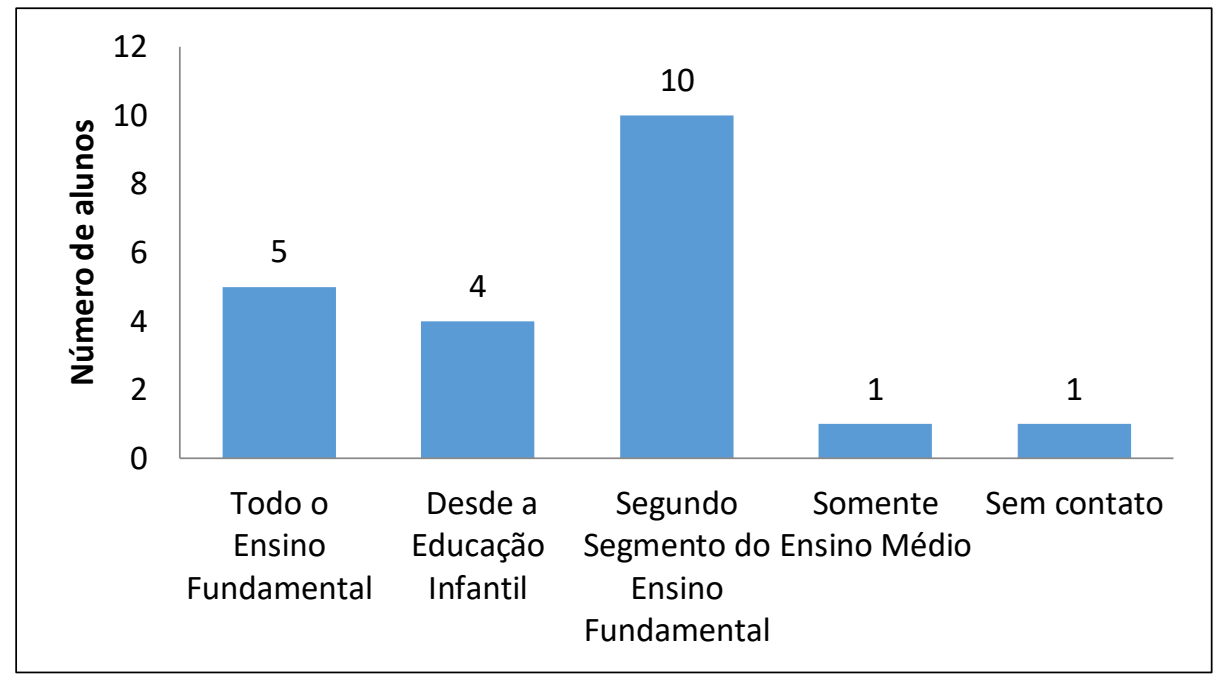

Fonte: Dos autores, 2019.

Embora a maioria da turma tenha tido contato com a Língua Inglesa durante a Educação Básica, os alunos classificaram como insatisfatório o próprio nível de conhecimento. Portanto, o contato com o idioma, na trajetória escolar, não determinou bom desempenho.

Figura 2. Classificação do nível de conhecimento na Língua Inglesa.

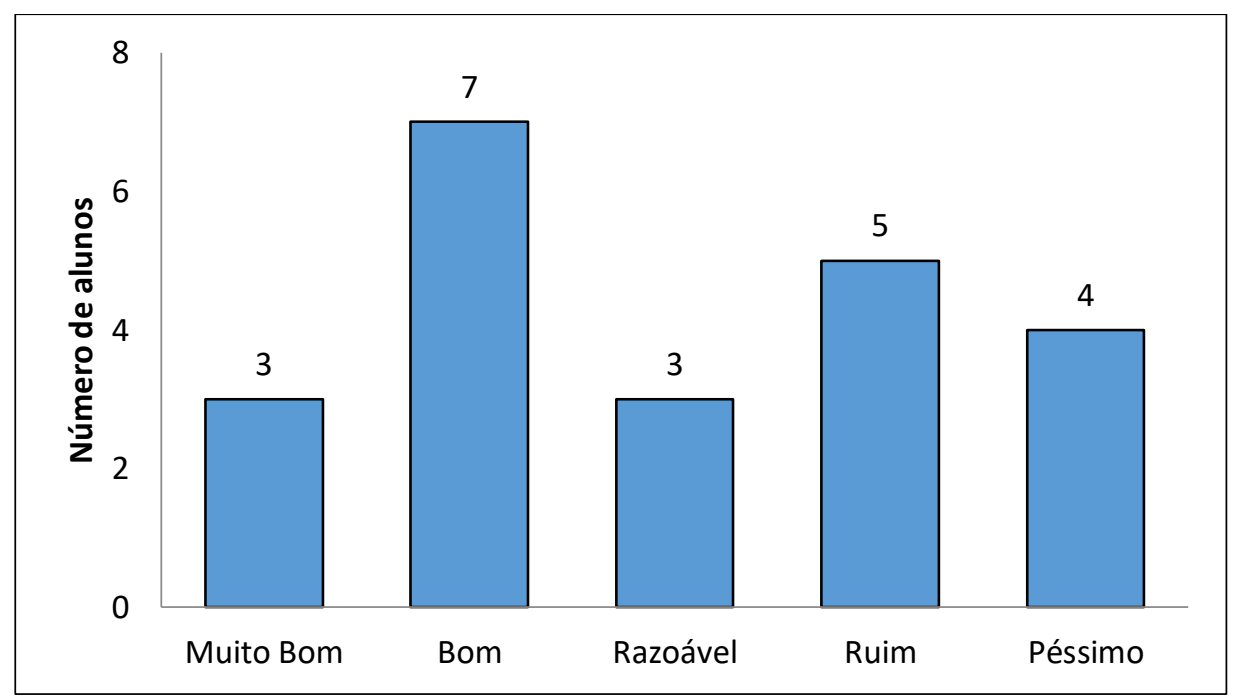

Fonte: Dos autores, 2019.

Diante da aprendizagem insatisfatória, a frustração parece não estar relacionada ao gosto e interesse pelo idioma, uma vez que os alunos concordam que é importante aprender Inglês. A frustração parece decorrer da forma como se vem lidando com esse idioma na sala de aula, conforme atestam as falas a seguir:

O jeito que eu aprendi Inglês, 30, 40 anos atrás, não é diferente do jeito do meu filho. É igual. É listening comprehension, é preencher lacuna, não tem 
diferença. Não mudou absolutamente nada. Meu filho tem dez anos. Pro Inglês que eu tive na escola e depois pro cursinho, a mesma coisa. Talvez as crianças menores, como ele, estejam mais interessadas em Inglês do que eu fui. Não sei se por conta da mídia, essa história de computador e tal, eles acabam pegando mais rápido, mas o jeito de ensinar Inglês é igualzinho. Os textos, é, os listenings, é listening, depois, repeat o que entendeu, igual. (Aluna da turma)

Pessoalmente, eu não sei falar (Inglês) porque eu acho também que o nosso país tem uma Educação Básica fraca, principalmente na Língua Estrangeira. Pra mim, que fui criada lá na Região Nordeste, estudei, desde a fase infantil, só que nessa parte de idiomas, realmente, até muitos professores não passam disso que os alunos acabaram de falar, daquele bem básico mesmo, então, é complicado e, muitas vezes, hoje, pra você realmente aprender, tem que fazer um curso caríssimo e, muitas vezes, você não consegue falar. (Aluna da turma)

Embora, diante da turma, a maioria dos alunos tenha demonstrado sentir-se à vontade para a comunicação em Inglês, no somatório entre os que não se sentem e os que dizem que às vezes se sentem à vontade, o quantitativo é o mesmo. Falar em outro idioma requer uma exposição com a qual, na escola regular, os alunos não estão habituados.

Figura 3. Gráfico com as respostas dos alunos sobre sentir-se à vontade para se comunicar em inglês diante de sua turma.

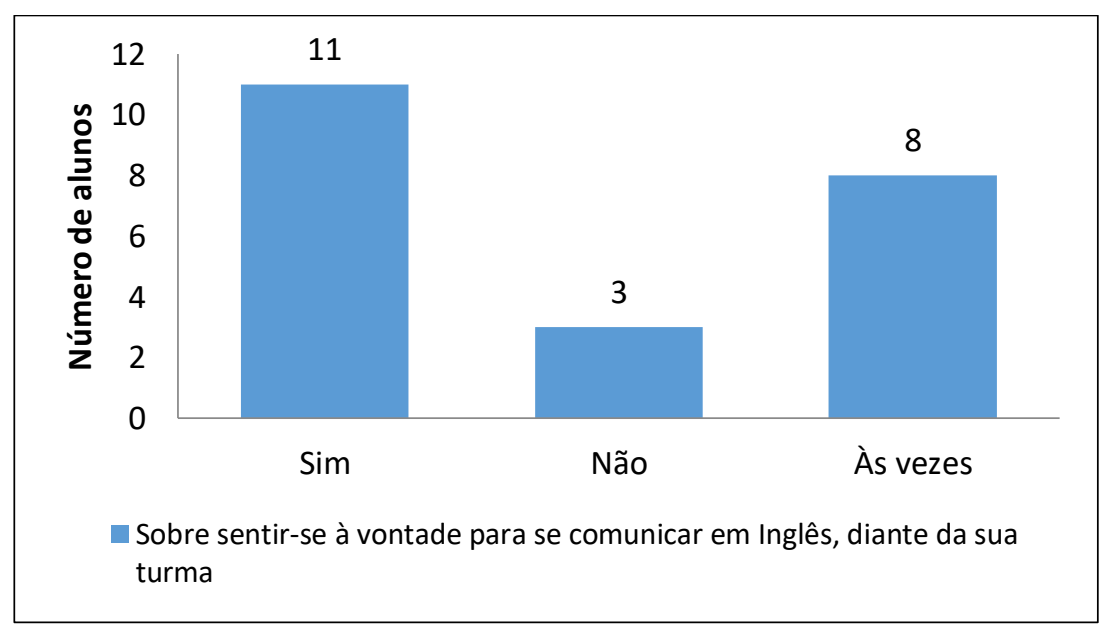

Fonte: Dos autores, 2019.

Talvez por esse motivo, quando se trata da expressão de preferências, as habilidades de ler e escrever sobrepõem-se a de falar. 
Figura 4. Gráfico sobre a preferência da prática da Língua Inglesa.

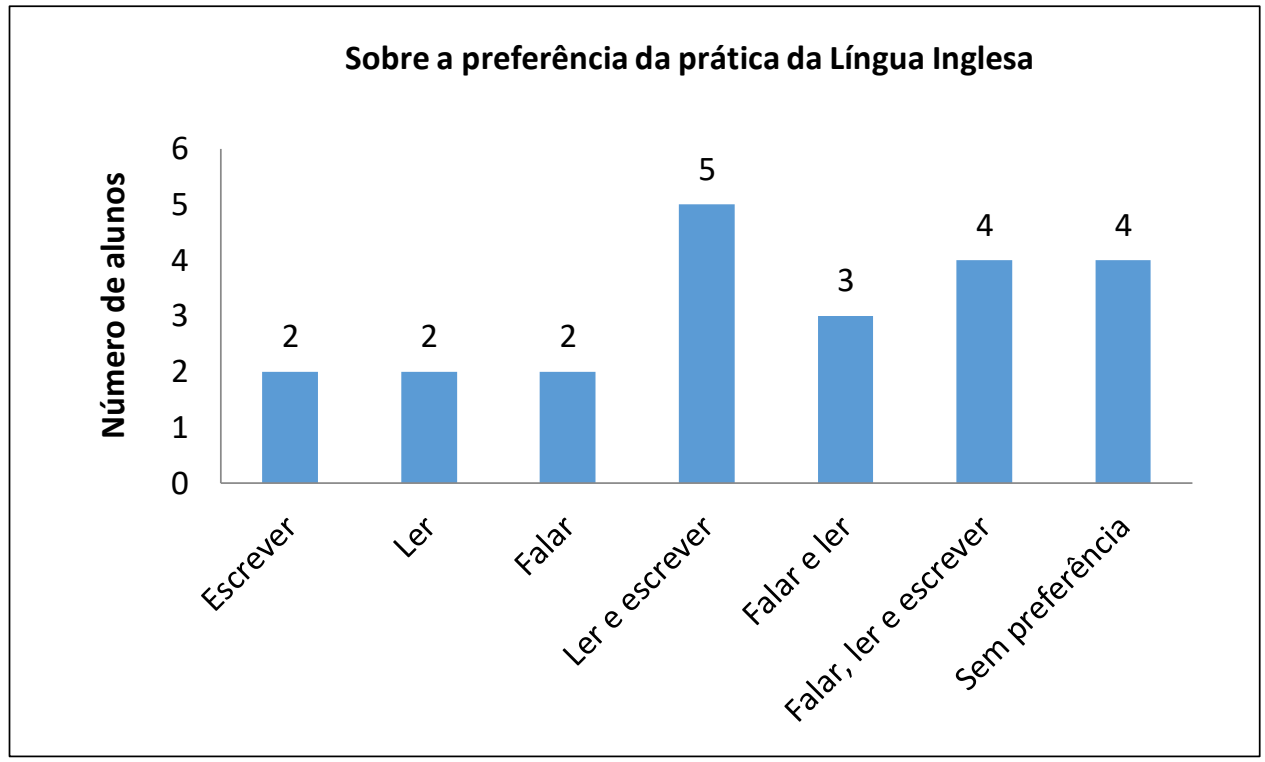

Fonte: Dos autores, 2019.

Isso aponta para a necessidade de mobilização, por parte dos professores e de todos os alunos envolvidos, porque se trata da composição de um grupo, para a construção e fortalecimento do sentimento de pertencimento, mesmo que o grupo seja ou pareça bastante heterogêneo. $\mathrm{O}$ fato de sentir-se à vontade para a comunicação em Inglês, manifestado por onze alunos, pode ter relação com a amizade há tempos estabelecida entre esses alunos da turma, tornando a experiência da comunicação menos difícil.

O não sentir-se à vontade para a comunicação em Inglês pode ter sido gerado ao longo do processo de escolarização, em que o erro pode ter sido considerado um objeto de exclusão, não um elemento da formação. É preciso considerar que, no processo escolar, o aluno pode errar, e que a apreciação do professor sobre a sua produção não deve ser um motivo de exclusão.

É possível que a satisfação com os estudos, demonstrada pelos alunos, promova a liberdade de fala, de comunicação, pois "tomar a palavra diante de um grupo depende de uma decisão pessoal: é preciso vencer o medo, manter o controle, "assumir-se", como se costuma dizer" (MEIRIEU, 2005, p. 77). A liberdade de fala e expressão foi amplamente enfatizada e concretizou-se no exercício das atividades autorreguladas. Todos os dados apresentados foram coletados por meio de questionário, sendo a sua análise basilar para o planejamento das atividades propostas na sequência didática. Consolidado o perfil da turma, a sequência didática planejada foi aplicada, no período de 09 de abril a 04 de junho de 2019, conforme descreve a Figura 5. 
Figura 5. Planejamento da Sequência Didática.

\begin{tabular}{|c|c|c|}
\hline ENCONTROS & OBJETIVOS & ATIVIDADES \\
\hline $\begin{array}{c}\text { Encontro } 1 \\
2 \text { h/a }\end{array}$ & $\begin{array}{l}\text { - Conhecer o perfil da turma e a } \\
\text { expectativa dos alunos quanto ao } \\
\text { estudo da Língua Inglesa no Curso } \\
\text { Técnico em Eventos. }\end{array}$ & $\begin{array}{l}\text { - Roda de conversa inicial e } \\
\text { aplicação de questionário contendo itens } \\
\text { relacionados às vivências individuais e aos } \\
\text { fatores socioemocionais; } \\
\text { - Levantamento dos conhecimentos } \\
\text { prévios da turma sobre a Língua Inglesa, } \\
\text { assim como da relação desse } \\
\text { conhecimento com cada aluno (reflexão } \\
\text { sobre trajetórias de aprendizagem e } \\
\text { posterior relato de experiências); } \\
\text { da Leitura de fragmento de um poema } \\
\text { da escritora Kamala Das, sobre a } \\
\text { conquista de um idioma, como disparador } \\
\text { motivacional para o debate. }\end{array}$ \\
\hline $\begin{array}{c}\text { Encontro } 2 \\
2 \mathrm{~h} / \mathrm{a}\end{array}$ & $\begin{array}{l}\text { - Planejar coletivamente as ações } \\
\text { a serem desencadeadas nas aulas } \\
\text { de Língua Inglesa, visando atingir } \\
\text { os objetivos propostos para a } \\
\text { área, discutindo as ações e } \\
\text { estratégias a a serem } \\
\text { desenvolvidas; } \\
\text { - Fazer o levantamento do } \\
\text { vocabulário a ser trabalhado no } \\
\text { decorrer do curso, a partir das } \\
\text { relações afetivas e emocionais. }\end{array}$ & $\begin{array}{l}\text { - } \quad \text { Discussão da proposta de trabalho; } \\
\text { - } \quad \text { Escolha individual de um evento de } \\
\text { sua preferência; } \\
\bullet \quad \text { Listagem de palavras ou } \\
\text { expressões relacionadas a cada evento } \\
\text { escolhido; } \\
\text { - Socialização das narrativas sobre o } \\
\text { motivo da escolha de cada evento e de } \\
\text { suas palavras representativas. }\end{array}$ \\
\hline $\begin{array}{c}\text { Encontro } 3 \\
2 \mathrm{~h} / \mathrm{a}\end{array}$ & $\begin{array}{l}\text {-Desenvolver habilidades } \\
\text { necessárias à pesquisa; } \\
\text { - Conhecer e/ou ampliar o } \\
\text { conhecimento de vocabulário em } \\
\text { Inglês, relativo a eventos. }\end{array}$ & $\begin{array}{l}\text { - A partir da escolha dos eventos em } \\
\text { comum (casamento, evento esportivo, } \\
\text { aniversário, Natal, festa junina e } \\
\text { formatura), organização dos grupos, } \\
\text { comparação de palavras e listagem de } \\
\text { vocabulário relevante, além de acréscimo } \\
\text { de palavras que, porventura, não } \\
\text { surgissem individualmente; } \\
\text { • Reconhecimento do grupo, } \\
\text { identificando as habilidades individuais e } \\
\text { as competências da equipe. }\end{array}$ \\
\hline $\begin{array}{c}\text { Encontro } 4 \\
2 \mathrm{~h} / \mathrm{a}\end{array}$ & $\begin{array}{l}\text { - Desenvolver habilidades } \\
\text { necessárias à pesquisa; } \\
\text { - Conhecer e/ou ampliar o } \\
\text { conhecimento de vocabulário em } \\
\text { Inglês, relativo a eventos. }\end{array}$ & $\begin{array}{l}\text { - Trabalho dos grupos: } \\
\text { 1. Apresentação das primeiras } \\
\text { traduções, em Inglês, das palavras } \\
\text { e expressões elencadas por cada } \\
\text { grupo; } \\
\text { 2. Recomendação dos sites de } \\
\text { dicionários e de pronúncia mais } \\
\text { comumente utilizados pelos } \\
\text { aprendizes do idioma. }\end{array}$ \\
\hline $\begin{array}{c}\text { Encontro } 5 \\
2 \mathrm{~h} / \mathrm{a}\end{array}$ & $\begin{array}{l}\text { Desenvolver habilidades } \\
\text { necessárias à pesquisa; } \\
\text { Ampliar o conhecimento de } \\
\text { vocabulário, em Inglês, } \\
\text { relativo a eventos; } \\
\text { Desenvolver a autonomia, } \\
\text { a partir das atividades } \\
\text { autorreguladas. }\end{array}$ & $\begin{array}{l}\text { - Roda de conversa com os grupos } \\
\text { para a identificação de demandas } \\
\text { individuais mais específicas; } \\
\text { - Sugestão de atividades } \\
\text { direcionadas a cada grupo, a partir } \\
\text { das demandas apresentadas. }\end{array}$ \\
\hline
\end{tabular}




\begin{tabular}{|c|c|c|}
\hline $\begin{array}{c}\text { Encontro } 6 \\
2 \mathrm{~h} / \mathrm{a}\end{array}$ & $\begin{array}{l}\text { Desenvolver habilidades } \\
\text { necessárias à pesquisa; } \\
\text { Ampliar o conhecimento de } \\
\text { vocabulário, em Inglês, } \\
\text { relativo a eventos; } \\
\text { Desenvolver a autonomia, } \\
\text { a partir das atividades } \\
\text { autorreguladas. }\end{array}$ & $\begin{array}{l}\text { - Discussão e estudo do vocabulário } \\
\text { selecionado: trabalho individual e } \\
\text { coletivo (em cada grupo); } \\
\text { - Planejamento inicial das } \\
\text { apresentações }\end{array}$ \\
\hline $\begin{array}{c}\text { Encontro } 7 \\
2 \mathrm{~h} / \mathrm{a}\end{array}$ & $\begin{array}{l}\text { Ampliar o conhecimento de } \\
\text { vocabulário, em Inglês, } \\
\text { relativo a eventos; } \\
\text { Desenvolver a autonomia, } \\
\text { a partir das atividades } \\
\text { autorreguladas. }\end{array}$ & 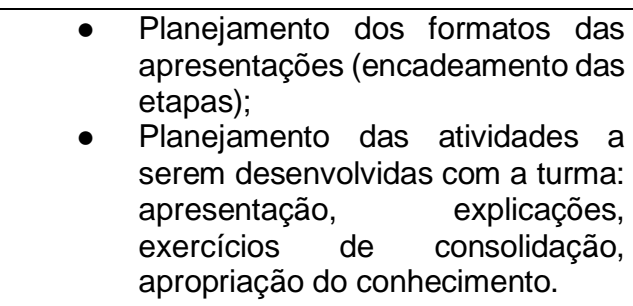 \\
\hline $\begin{array}{l}\text { Encontro } 8 \\
2 \mathrm{~h} / \mathrm{a}\end{array}$ & $\begin{array}{l}\text { - Apropriar-se do vocabulário } \\
\text { relacionado aos eventos } \\
\text { previamente selecionados; } \\
\text { - Socializar o conhecimento. }\end{array}$ & $\begin{array}{l}\text { Apresentação dos trabalhos dos grupos } \\
\text { casamento, festa junina e formatura. }\end{array}$ \\
\hline $\begin{array}{c}\text { Encontro } 9 \\
2 \mathrm{~h} / \mathrm{a}\end{array}$ & $\begin{array}{l}\text { Apropriar-se do vocabulário } \\
\text { relacionado aos eventos } \\
\text { previamente selecionados; } \\
\text { - } \quad \text { Socializar o conhecimento. }\end{array}$ & $\begin{array}{l}\text { Apresentação dos trabalhos dos grupos } \\
\text { evento esportivo, aniversário e Natal. }\end{array}$ \\
\hline $\begin{array}{l}\text { Encontro } 10 \\
2 \mathrm{~h} / \mathrm{a}\end{array}$ & $\begin{array}{l}\text { - Avaliar o processo de } \\
\text { aprendizagem; } \\
\text { - Socializar as experiências } \\
\text { vividas. }\end{array}$ & $\begin{array}{l}\text { - Roda de conversa final: relato das } \\
\text { impressões, críticas e sugestões, com a } \\
\text { exposição, perante o grupo e a } \\
\text { professora, do que se vivenciou; } \\
\text { - Avaliação do conhecimento sobre a } \\
\text { Língua Inglesa, desenvolvido no } \\
\text { bimestre em questão, no Curso Técnico } \\
\text { em Eventos. }\end{array}$ \\
\hline
\end{tabular}

Como disparador motivacional, na tentativa de suscitar reflexões e considerações dos alunos a respeito da importância do conhecimento do idioma já conquistado por cada um deles, e de suas próprias trajetórias de aprendizagem, procurando afastá-los de qualquer julgamento sobre a qualidade desse conhecimento, logo no primeiro encontro, foi feita a leitura do fragmento de um poema da escritora indiana Kamala $\operatorname{Das}^{4}$, propositadamente escolhido porque escrito naquele que não é o idioma oficial do seu país de origem. Essa tarefa aproximou o grupo.

No segundo encontro, realizou-se a primeira atividade: individualmente, os alunos deveriam escolher o evento de sua preferência e listar as palavras, escritas em Língua

\footnotetext{
${ }^{4}$ O poema foi retirado do Caderno de Provas do Exame Nacional do Ensino Médio (ENEM), 2018.
} 
Portuguesa, relacionadas a esse evento. As palavras apresentadas oralmente traduziram, em grande parte, memórias de infância e de juventude, permeadas, por conseguinte, de uma carga afetiva bastante significativa, e a turma demonstrou muito interesse em identificar as coincidências, tanto em relação às palavras citadas como às emoções vinculadas a essas palavras.

No terceiro encontro, a turma foi organizada em grupos a partir dos eventos elencados e da lista de eventos disposta no quadro da sala de aula. Os eventos citados foram: formatura, aniversário, casamento, Natal, festa junina e evento esportivo. Como os grupos foram formados pelos eventos listados individualmente, não havia a possibilidade de previamente determinar a quantidade de grupos e de componentes. O que havia anteriormente previsto, é que, se porventura houvesse total incompatibilidade de ideias, ou se o evento de algum aluno ficasse sem representatividade, os próprios alunos deveriam dialogar e se reorganizar, chegando a um consenso baseado em um mínimo de afinidade.

Posteriormente, os alunos interessados nos mesmos eventos se reuniram para escolher, entre o vocabulário presente em suas listas individuais, quais palavras seriam aproveitadas, uma etapa bastante significativa, pois foram orientados a pensar por que as palavras deveriam ou não constar de um glossário técnico sobre um evento, assim como até que ponto as suas próprias palavras seriam relevantes para os demais, para o trabalho e para a disciplina de Língua Inglesa, dentro do curso.

O quarto encontro se deu nas sétima e oitava aulas, ocasião na qual os componentes de cada grupo apresentaram as primeiras traduções, em Inglês, das palavras e expressões listadas pelo grupo. O apoio da professora restringiu-se a recomendações dos sites de dicionários e de pronúncia mais comumente utilizados por aprendizes do idioma, além de ajustes eventuais de determinados termos, com relação à sua categoria morfológica e à sua adequação ao contexto de eventos.

No quinto encontro, uma nova rodada de conversas com os membros de cada grupo, permitiu identificar, em particular, demandas individuais mais específicas, fato que possibilitou à professora escoltá-los, no sentido de propor a realização de algumas estratégias de aprendizagem, como, por exemplo, a recomendação de elaboração de pequenos mapas conceituais, um recurso mnemônico comprovadamente eficaz. Antes, porém, propôs-se um exercício de reflexão individual, a se realizar paralelamente à execução das etapas da sequência, para que cada aluno procurasse pensar sobre o seu jeito de melhor aprender as palavras novas 
do idioma, desenvolvendo, assim, as estratégias particulares que lhe conviesse. Esse contato com os grupos, também oportunizou algumas elucidações sobre diferenças de palavras do Inglês britânico para o americano, além de distinções ortográficas e de pronúncia, em consonância com a ementa do curso, que propõe uma incursão em algumas características da cultura britânica e americana.

O sexto encontro acolheu o planejamento, pelos componentes dos grupos, das apresentações dos eventos. A professora permaneceu na sala de aula, em total disponibilidade, interagindo com os alunos, apenas quando solicitada. Os quarto, quinto e sexto encontros objetivaram promover, por meio do trabalho em grupo, o desenvolvimento de habilidades necessárias à pesquisa.

No sétimo encontro, em um primeiro momento, os alunos reuniram-se para organizar a ordem de apresentação das etapas para a professora. Dentro da proposta de diminuição gradativa de assistência, dando ainda mais responsabilidade aos grupos, a professora limitouse a circular pela sala. Viabilizou-se identificar o quanto as estratégias de ensino da Língua, usadas por ela, ao longo do módulo em curso, e mesmo do módulo anterior, fizeram parte das tarefas elaboradas pelos grupos. Em um segundo momento, cada grupo levou à professora seus esquemas detalhados de apresentação. Esse foi o último encontro antes das apresentações dos trabalhos.

Os oitavo e nono encontros foram dedicados às apresentações. Em cada encontro, aconteceram três apresentações. No oitavo, apresentaram-se os seguintes grupos: casamento, festa junina e formatura. No nono, evento esportivo, aniversário e Natal. Definiu-se que o tempo de cada apresentação não deveria ultrapassar vinte minutos.

No décimo encontro, para finalizar a sequência didática, foi feita última roda de conversa, para que os alunos se expusessem, perante o grupo e a professora, apresentando suas considerações a respeito de tudo o que foi vivido, tanto em relação à aprendizagem da Língua Inglesa, quanto em relação ao seu empenho e envolvimento nas tarefas.

Como produto final da sequência didática, cada grupo de trabalho responsabilizou-se por apresentar e ensinar a lista de vocabulários relativa ao evento escolhido.

\section{A AUTORREGUlaÇÃo NA SEQUÊNCIA DIDÁTICA: O QUE SE APRENDEU?}

A sequência didática aplicada envolveu o estudo sobre o vocabulário relacionado a diferentes eventos, com elementos afetivos, buscando a promoção da autorregulação da 
aprendizagem dos alunos. Como produto educacional produzido, foi a grande estratégia metodológica que associou o trabalho ao vocabulário técnico do curso de educação profissional, a partir da consideração e desenvolvimento da afetividade.

Para Brown et al (apud EWIJK e WERF, 2012), no nível mais elementar sobre a aprendizagem autorregulada, a que chamam de treinamento cego, os alunos são induzidos a usar uma estratégia, sem que lhes seja oferecida qualquer informação sobre ela, exatamente para promover uma compreensão simultânea paralela sobre o significado da atividade. Não se revela por que usar uma estratégia, ou em que situação uma atividade é apropriada, o que quer dizer que alunos realizam a atividade sem a informação de que a atividade é uma estratégia de aprendizagem.

Com os relatos dos alunos, permeados pelas emoções das experiências vividas, é possível perceber que o professor pode entender, interpretar e influenciar as emoções, de maneira produtiva, em sala de aula. Tal compreensão também sugere uma possibilidade de motivação, de ampliação de conhecimento mais aprofundado e de transferência de habilidades para o mundo real, conforme diz Immordino-Yang (2016). Continua a autora dizendo que para formar alunos informados, hábeis, éticos e reflexivos, é necessário encontrar maneiras de aperfeiçoar os aspectos emocionais da aprendizagem na educação. As emoções são programas de ação que se desenvolvem como extensões de mecanismos de sobrevivência (IMMORDINOYANG, 2016).

Seguindo a dinâmica proposta, os trabalhos foram realizados em grupo, o que favoreceu o reconhecimento do outro como parte fundamental para o funcionamento e para a eficiência do projeto, pois implicou nas ações de todos os sujeitos envolvidos para a constatação e identificação com o vocabulário construído. A mediação da professora evidenciou-se na escuta e posterior contribuição na seleção e organização do vocabulário, a partir dos diálogos com os alunos. O diálogo é a ação que vai além de uma estratégia a ser utilizada em aula, pois ele "é o momento em que os humanos se encontram para refletir sobre sua realidade tal como a fazem e re-fazem" (SHOR e FREIRE, 1986, p. 123). E mais,

Não podemos, não devemos, entender o diálogo como uma tática que usamos para fazer dos nossos alunos nossos amigos. Isto faria do diálogo uma técnica para a manipulação, em vez de iluminação. Ao contrário, o diálogo deve ser entendido como algo que faz parte da própria natureza histórica dos seres humanos. É parte de nosso progresso histórico do caminho para nos tornarmos seres humanos. (SHOR e FREIRE, 1986, p. 122) 
Os encontros de trabalho objetivaram promover o desenvolvimento de habilidades necessárias à pesquisa. A socialização da descoberta de que não existem palavras ideais para traduzir muitas palavras com as quais o brasileiro está completamente habituado, como pastel, por exemplo, a compreensão de que, na comunicação com um falante nativo do Inglês, dependendo de um contexto esclarecedor, pode-se fazer uso de sua própria língua, foram fatores relevantes nos estudos e pesquisas.

Os alunos tiveram plena consciência do compromisso assumido com os demais e com a professora, compreendendo que não somente apropriar-se de um vocabulário novo, em Inglês, mas, principalmente, conseguir trabalhar esse vocabulário, de modo que a organização de cada etapa do processo alcançasse uma aprendizagem a ser constatada por eles mesmos, ao final, causou muita expectativa e uma certa insegurança. Algumas perguntas indicativas dessa insegurança surgiram no decorrer dos encontros, durante todo o processo, nas rodas de conversas e nas orientações específicas nos grupos, como: "Professora, esse vocabulário da gente é o vocabulário que você ia ensinar? E se ficar faltando?", "Se a gente se enrolar, na hora, você vai ajudar?"

Segundo Ewijk e Werf (2012), a investigação sobre o conhecimento do professor e as suas crenças a respeito da aprendizagem autorregulada revela que, de fato, é interesse do professor promover a autonomia em sala de aula, mas esse professor não se sente seguro acerca do domínio das estratégias de aprendizagem que podem ajudar o aluno a lidar com essa autonomia. Continuam os autores dizendo que o professor acredita que a autorregulação da aprendizagem é positiva, mas não dispõe do conhecimento necessário para promovê-la. De acordo com esses autores, uma questão para pesquisas futuras é a inconsistência entre a crença e a prática do professor. Por um lado, reconhecer a importância da proposta e, por outro lado, ao mesmo tempo, não se sentir preparado para adotá-la.

Existem equívocos, por parte dos professores, na clara identificação dos instrumentos para efetivamente lidar com a autonomia pretendida. Uma compreensão teórica limitada ou inadequada pode levar a uma experiência de frustração entre alunos e professores, o que aponta para a necessidade de um treinamento. Daí, a indispensabilidade de ajudar o professor, já na sua formação profissional, a desenvolver uma maneira eficaz de integrar a autorregulação da aprendizagem ao seu cotidiano escolar (EWIJK e WERF,2012).

Um estudo realizado pelos autores acima citados, mostrou que o professor já apresenta uma postura acolhedora, quando se fala em autorregulação de aprendizagem, no quesito 
autonomia. A reflexão deve ser se o quadro positivo resultante do estudo constitui um ponto de partida para quem prepara o professor, ou se, em vez disso, representa apenas um conjunto de ideias de professores sobre como eles deveriam pensar.

Existem mais variáveis que afetam o comportamento do professor. Tais variáveis vão além dos conceitos, são um teste de eficiência. Apesar de aprová-la, o professor não se sente capaz, portanto, não integra a autorregulação de aprendizagem à sua atividade, por melhor que ela lhe possa parecer (EWIJK e WERF, 2012).

Com base na formação e/ou capacitação para os professores sobre a autorregulação da aprendizagem, os autores Kramarski e Revach (apud EWIJK e WERF, 2012) concluem que o desenvolvimento profissional do professor pode ser a causa da não implementação da proposta. Há que se ter em mente que as crenças do professor influenciam a percepção da nova informação. Segundo os autores, essa formação deve acontecer o quanto antes, desde a formação inicial, pois o professor começa a carreira docente usando métodos tradicionais de ensino trazidos das suas próprias experiências como aluno e, também, porque, em determinado momento,-desenvolve as suas próprias crenças, potencialmente incorretas, sobre aprendizagem autorregulada, ancoradas na sua experiência de ensino. Essas crenças começam a influenciar as suas percepções da nova informação. É importante quebrar o paradigma: mudar a crença do professor, antes que isso aconteça.

Nos últimos encontros de estudos, constatou-se que os alunos, pela observação, foram, gradativamente, internalizando não somente conteúdos, mas também processos, aprendendo a aprender. Duas considerações importantes devem ser feitas sobre esses últimos encontros. A primeira envolve o impacto da socialização da aprendizagem: o entrosamento dos componentes dos grupos e a uniformidade na participação de cada aluno. A afinidade com o evento escolhido, gostar da festa sobre a qual iriam falar, conhecer histórias dos colegas relacionadas à festa, tudo isso se traduziu em motivação. Motivação sem ansiedade. De fora, não era possível reconhecer quais alunos tinham mais conhecimento do idioma. A busca era o desenvolvimento da competência do grupo, por meio da análise crítica daquelas produções, uma reflexão sobre se estavam fazendo o certo.

A segunda consideração envolve o sentimento de concordância, de aceitação de uma provocação, por parte dos alunos, quando se mostraram tão dispostos a assumir uma posição tradicionalmente ocupada pela professora, mais uma vez, sem ansiedade. Uma hipótese para tal pode ser a percepção de que, sendo falante não nativa do idioma, a professora lida com tal 
desafio, cotidianamente. Em outras palavras, a compreensão, em última instância, de que a aprendizagem é uma atividade essencialmente colaborativa, de interação social, que se dá em contexto, conhecendo o que se sabe para poder prosseguir, estando esses princípios intimamente ligados à aprendizagem autorregulada. Stephen Krashen (apud SIBOMANA, 2014) desenvolveu uma série de hipóteses sobre aquisição de uma segunda língua. Uma delas, Sibomana (2014) esclarece, é a hipótese do filtro afetivo, que abrange variáveis afetivas e sócioemocionais. As variáveis afetivas mais favoráveis à aquisição de uma segunda língua são um ambiente de aprendizagem com baixa ansiedade, a motivação do aluno para aprender a língua, a autoconfiança e a autoestima.

A aprendizagem se dá, mediante a abrangência das contribuições pedagógicas, quando os filtros afetivos estão baixos o suficiente. Por essa razão, escutar e entender a língua é essencial ao processo de aprendizagem. Propõe-se, assim, que não se force tão rapidamente a produção do aluno, concedendo a ele um período de silêncio no qual a aquisição do conhecimento da língua resulta dessa escuta e dessa compreensão, em contraponto às tradicionais repetições mecânicas e sem significado (SIBOMANA, 2014).

Yule (apud SIBOMANA, 2014), argumenta que um filtro afetivo alto anula quaisquer habilidades físicas e cognitivas que o aluno tenha. Du (apud SIBOMANA, 2014), aponta, como causas de um filtro afetivo alto, a falta de motivação, a falta de confiança e a preocupação com o fracasso. O filtro está baixo, ele acrescenta, quando o aluno não está ansioso e está tentando se tornar membro daquele grupo de falantes. Sibomana (2014) considera que, apesar de os filtros afetivos variarem, de pessoa para pessoa, os contextos de aprendizagem diminuem ou aumentam esses filtros. O filtro afetivo pode aumentar, em um contexto no qual a acurácia predomina sobre a fluência, em que os erros são objeto de julgamento. $O$ filtro afetivo aumentado reduz, assim, a produção do aluno. É importante, portanto, ele sugere, que o aumento do filtro afetivo seja evitado ou minimizado, no processo.

Na sequência do trabalho, cada grupo, separadamente, levou à professora seus esquemas detalhados de apresentação. Como orientação inicial, cada grupo deveria não somente elucidar o vocabulário construído sobre um evento determinado, mas ensiná-lo para toda a turma. Foi aí que se percebeu, ainda, a necessidade de alguns pequenos ajustes, especialmente quanto à duração das etapas, pois os alunos pareciam não se dar conta do nível de dificuldade das atividades que estavam propondo, possivelmente um indicativo de que sentiam-se seguros sobre o que estavam prestes a apresentar, sem levar em consideração o tempo de assimilação 
de cada proposta pelos colegas, em uma turma relativamente heterogênea, em termos de conhecimento de Língua Inglesa.

O fato de os alunos conhecerem a ementa e terem consciência de que parte dela estava sob seus cuidados, já que a professora não apresentaria os conteúdos, ativou, de modo muito positivo e eficaz, um sentimento de responsabilidade sobre a aprendizagem dos colegas, paralelamente à sua aprendizagem.

Ao final de um processo avaliado em todos os momentos, em todas as etapas, concebeuse que "o ser humano age em função de algum resultado, seja econômico, material, político, amoroso, ou até mesmo o simples prazer de viver o momento" (LUCKESI, 2002, p. 152). Com a ideia de favorecer o desenvolvimento da autorregulação afetiva e efetiva na aprendizagem da Língua Inglesa, as atividades foram propostas e realizadas de forma a promoverem o acolhimento, a integração e a inclusão. No transcurso da sequência didática, o professor não se isentou de sua tarefa, tomando plena consciência do seu envolvimento e compromisso com os alunos, incluindo o ato de avaliá-los, ao final do módulo do curso, ponderando que

se formos conscientes do nosso envolvimento nos juízos de valor estabelecidos, iremos encarar com maior seriedade as nossas decisões. Não significa, entretanto, a ausência de rigor ou cientificidade da testagem nos cursos ou concursos, nem mesmo a falta de objetividade nos métodos de observação e acompanhamento do desempenho dos alunos, mas o resgate à sensibilidade inerente ao processo. Ou seja, estarmos conscientes de que a educação envolve a relação entre seres humanos, diferentes entre si, que guardam seus próprios mistérios e que não haverá métodos ou processos infalíveis para compreendê-los em sua plenitude. O que um professor percebe a respeito do aluno pode ser diferente do que outro professor percebe e, provavelmente, diferente de como os alunos ou os seus colegas o percebem. O que significa edificar o processo avaliativo no terreno das hipóteses e não das certezas. (HOFFMANN, 2007, p. 17).

Para finalizar, após as apresentações dos grupos, promoveu-se uma roda de conversa, para que os alunos se expusessem perante o grupo e a professora, apresentando suas considerações a respeito de tudo o que foi vivido, a partir da sequência didática implementada, tanto em relação à aprendizagem da Língua Inglesa, quanto em relação ao seu empenho e envolvimento. Com o consentimento de todos, a roda de conversa final foi gravada, ficando assim, as falas catalogadas. É impossível registrar os olhares, alguns marejados, outros brilhantes, bem como os sorrisos e a emoção transmitida com palavras e gestos. Mas aqui seguem, na íntegra, algumas falas. Embora muitas e longas, as falas que seguem retratam a 
visão dos alunos, e seria impossível deixá-las de fora. O destaque nas falas feitas pela autora, a própria professora, representam a afirmação de todo o contexto teórico que embasou o trabalho:

Eu acho que esse é o problema das pessoas, é a didática do professor. Se a pessoa ficar ali, muito na apostila, ela não vai aprender nada porque ela vai ficar decorando as coisas pra fazer uma prova, que vai passar e ela vai esquecer tudo. Com uma didática diferente, talvez o aluno consiga aprender sem decorar as coisas. (Aluno 1)

Ela falou de didática e realmente, por exemplo, eu fiquei 3 anos no (cita um curso específico), e eu não conseguia falar. Minha mãe falou que a didática de lá é a mesma do tempo dela. (Aluno 2)

Gostei muito do tema CASAMENTO, uma coisa que eи e meu irmão, a gente está relacionado por causa da música, isso é muito legal, eu gosto muito. Eu fiquei muito feliz porque eu gosto muito de Inglês e eu amo séries; meu sonho é assistir séries sem legenda, meu sonho é passar 24 horas do dia falando só em Inglês. Quero agradecer pelas atividades, fez eu ter uma pronúncia melhor, algumas palavras que eu tinha dúvida, fez eu melhorar bastante. (Aluno 3)

Todos os métodos que eu vi ensinarem não foi igual ao que eu vi aqui. Na primeira aula de Inglês, que eu estava morrendo de medo, a professora Adriana chegou na sala falando Inglês, eu falei: "gente, eu não sei o que eu tô (sic) fazendo aqui”. Eu achava que eu sabia Inglês, mas eu não sabia nada. Esse trabalho da FORMATURA, é um evento que eu gosto muito e, tipo assim, só de falar meus olhos já brilham; querendo, ou não, eu não iria procurar aquelas palavras sozinhas, se eu não tivesse um incentivo, e ela deu esse incentivo pra gente escolher, foi muito legal, gosto muito do método dela; eu consigo aprender mais com ela do que eu achava que aprendia, e ai eu já percebi que, na verdade, o que eu aprendia não era bem, tipo assim, eu aprendia, porém, eu não sabia falar. Eu, na verdade, não aprendia e aqui eu consegui aprender, eu consegui falar e eu estou muito feliz. Vai ser muito triste deixar esse curso agora. (Aluno 4)

Uma coisa que a professora ensinou pra gente, dessa forma diferente dela lidar com a matéria, é que ela ensina a gente interligando com as nossas emoções também, ela faz um link do que a gente gosta, um link com o que a gente tem que aprender a palavra, ou seja, qual foi a matéria, ligando com o nosso pessoal, isso acaba ajudando a gente a decorar e assimilar melhor a matéria. Porque é uma coisa de dentro, é uma coisa que a gente entende, é uma coisa... é o nosso jeito de entender, então, é basicamente isso que a gente entende. A gente tem as nossas próprias escolhas pra poder entender melhor a matéria, eu não sei explicar direito, mas é basicamente isso. (Aluno 5)

O método aplicado que a senhora deu pra gente, pra mim foi muito bom. Eu aprendi muito. Esse então, da última aula foi maravilhoso! Os colegas do meu grupo foram perfeitos, me ajudaram muito e, com as dificuldades do trabalho, eu tive muita dificuldade de fazer o trabalho, mas eu aprendi muito, e o preparo, né, das palavras. O tema é um tema que eu gosto muito, CASAMENTO; e eu fiquei muito focada, muito empolgada. Nós fizemos aquilo que foi possível, mas eu gostaria de ter feito até mais, porque eu aprendi muito. Os meninos falando 
me ensinaram como falava as minhas palavras. Para mim foi importante tanto a disciplina como o grupo. O Inglês pra mim era um monstro e ele ficou bem pequeno, através da experiência. Eu gostei muito. (Aluno 6)

Eu fiquei assustada com a proposta, vocês não ficaram, não? Gente, eu pensei: "eu não sei nada de Inglês". Aí, quando eu vi que o trabalho fazia você fazer coisas dinâmicas, a dinâmica, o lúdico, é ótimo. A gente vive no papel, no quadro. Se você sair da carteira que você escreve, olha para o professor, o professor está lá na frente, e você se transporta, vai para o lugar do professor, é outra situação. Quando eu me transportei no lugar da professora de Inglês, né, gente, eu falei: "gente!" E vi os meus amigos de sala de aula se tornando professores e levando aquilo tudo pro quadro, não pra lousa, mas levando pro slide... eu senti assim, eu falei assim: "Gente, como a gente acha que a gente não é nada, né?". Quando a gente passa pro outro lado, pro lugar da professora, que a gente olha os nossos amigos fazendo o papel dela, lógico, não quanto ela, mas o papel que cada um sabe fazer, gente! Eu fiquei assim, cara, eu adorei as aulas. Nossa! Foram ótimas! Foram muito boas! Não sei se a professora achou a mesma coisa. Eu não sou a professora de Inglês, mas nós estamos de parabéns com a aula que nós tivemos. (Aplausos). (Aluno 7)

Os aplausos, ao final, não foram endereçados àquele que falava, mas, a cada um que se identificou com a fala, reconhecendo-se como sujeito e cidadão que se prepara para o mundo do trabalho, transbordante de afeto e emoção.

\section{CONSIDERAÇÕES FINAIS}

O Curso Técnico em Eventos recebe um público bastante heterogêneo, mas, caracterizado por vivências comuns, na relação com a Língua Inglesa. A sala de aula, portanto, reflete posturas que resultam de conceitos convencionalizados, já profundamente enraizados, no percurso de aprendizagem desses alunos. Entre eles, o entendimento de que aprender a Língua Inglesa significa dominar suas estruturas gramaticais, suas funções, seu vocabulário, em um nível tal de desenvolvimento de habilidades de compreensão auditiva, de escrita, e de fala, que possibilite uma comunicação incompatível com o tempo e com a natureza do trabalho realizado dentro dos limites da escola regular.

Assim, perde-se de vista a importante reflexão de que, ao ensinar um idioma estrangeiro, a que se trazer para a prática pedagógica a valorização dos pequenos planejamentos a serem desdobrados em curto prazo, levando-se em conta especificidades individuais privilegiando atividades em que o aluno procure alcançar certa maturidade e uma autonomia acerca do reconhecimento de suas próprias limitações, bem como de seus pontos fortes, sobretudo das estratégias que lhe permitam progredir, pouco a pouco, monitorando, por meio da 
autorregulação da aprendizagem das atitudes e das emoções, assim como da socialização de histórias em comum, seus próprios avanços.

Nessa perspectiva, o papel do professor ganha destaque, no sentido de favorecer manifestações de afetividade, sob a forma de flexibilidade e condescendência positivas, na valorização entusiasmada dos esforços demonstrados pelo aluno. Por isso, a necessidade do olhar atento e cuidado para a formação docente, seja inicial ou continuada, que constituirá as relações emocionais fecundas, uma vez que toda a prática pedagógica deve estar associada à dimensão afetiva.

\section{REFERÊNCIAS}

ABED, A. L. Z. O desenvolvimento das habilidades socioemocionais como caminho para a aprendizagem o sucesso escolar de alunos da Educação Básica. São Paulo, 2014.

ARAÚJO, D. L de. O que é (e como se faz) sequência didática? Entrepalavras, Fortaleza. v. 3, n.1, p.322-334, jan/jul 2013.

BEATO-CANATO, A. P. M. O trabalho com línguas para fins específicos em uma. Rev. Bras. Linguist. Apl. Vol.11, n.4, pp.853-870, 2011.

BEZERRA, R. J. L. Afetividade como condição para a aprendizagem: Henri Wallon e o desenvolvimento cognitivo da criança a partir da emoção. Revista Didática Sistêmica, Volume 4, julho a dezembro, 2006.

BEZERRA, D. S. Ensino Médio (des)integrado: história, fundamentos, políticas e planejamento curricular. Natal: IFRN, 2013.

BRASIL. Lei no 11.892 de 29 de dezembro de 2008, Institui a Rede Federal de Educação Profissional, Científica e Tecnológica, cria os Institutos Federais de Educação, Ciência e Tecnologia, e dá outras providências. Diário Oficial da República Federativa do Brasil, Brasília, 2008.

BRASIL. Lei de Diretrizes e Bases da Educação Nacional. Lei número 9394, 20 de dezembro de 1996.

CAMPELO, A. M. M. B; FILHO, D. L. L. Educação Profissional. Dicionário da Educação Profissional em Saúde. http://www.epsjv.fiocruz.br/publicacao/livro/dicionario-da-educacaoprofissional-em-saude-segunda-edicao-revista-e-ampliada. Acesso em 25/07/2019.

CITTOLIN, S. F. A afetividade e a construção de uma segunda língua: a teoria de Krashen e a hipótese do filtro afetivo. Revista das Letras, v. 6, 2003. 
CORREA, F. P. P.; B. K. S.; TOGNATO, M. I. R. Gêneros de texto por meio de práticas sociais em Língua Inglesa: o papel da sequência didática produzida por pibidianos. Ensino e Pesquisa. União da Vitória, v. 16, n. 3, p. 25-45, jul/set., 2018.

EWIJK, C.; WERF, G. What Teachers Think about Self-Regulated Learning: Investigating Teacher Beliefs and Teacher Behavior of Enhancing Students' Self-Regulation. HindawiPublishing Corporation. EducationResearchInternational. 10 pages. Volume 2012.

FERREIRA, L.M.C.B; ROSA, M. A. S. A origem do Inglês Instrumental. HELB - História do Ensino de Línguas no Brasil. Ano 2, No 2. 1/2008.

GANDA, D.R.; BORUCHOVITCH, E. A autorregulação da aprendizagem: principais conceitos e modelos teóricos. Psic. da Ed., São Paulo, 46, pp. 71-80,1º sem. de 2018.

HOFFMANN, J. Pontos \& Contrapontos: do pensar ao agir em avaliação. 10. ed., Porto Alegre, 2007.

IMMORDINO-YANG, M. H. Emotions Learning, and the Brain. Exploring The Educational Implications of Affective Neuoscience, W. W. Norton \& Company; Edição: 1, 2016.

KUENZER, A. Ensino Médio: Construindo uma proposta para os que vivem do trabalho. 6. ed. São Paulo: Cortez, 2009.

LEITE, S. A. S. (org). Afetividade: as marcas do professor inesquecível. Campinas, SP: Mercado das Letras, 2018.

LUCKESI, C. C. Avaliação da aprendizagem escolar. São Paulo: Cortez, 2002.

MEIRIEU, P., O Cotidiano da Escola e da Sala de Aula: o fazer e o compreender. trad. Fátima Murad. - Porto Alegre: Artmed, 2005.

POLYDORO, S. A. J.; AZZI, R. G. Autorregulação da aprendizagem na perspectiva da teoria sociocognitiva: introduzindo modelos de investigação e intervenção. Psic. da Ed., São Paulo, 29, pp. 75-94, $2^{\circ}$ sem. de 2009.

REGO, T. C..Vygotsky: uma perspectiva histórico-cultural da educação. 22. ed. Petrópolis, RJ: Vozes, 2011.

SHOR, I; FREIRE, P. Medo e Ousadia: O Cotidiano do Professor. 3. ed. Tradução de Adriana Lopez; revisão técnica de Lólio Lourenço de Oliveira - Rio de Janeiro: Paz e Terra, 1986.

SIBOMANA, E. The acquisition of English as a second language in Rwanda: challenges and promises. RwandanJournalofEducation - Volume 2, 2014. 
TRIPP, D.. Pesquisa-Ação: uma introdução metodológica. Educação e Pesquisa. São Paulo. V. 31. N. 3, p. 443-466, set/dez, 2005.

VYGOTSKY, L. S.. Pensamento e Linguagem. 4. ed. Tradução Jefferson Luiz Camargo: revisão técnica José Cipolla Neto. São Paulo: Martins Fontes, 2008. 